\title{
Pre-breeding: A Bridge between Genetic Resources and Crop Improvement
}

\author{
S.K. Jain* and Omprakash \\ College of Agriculture, Sri Karan Narendra Agricultural University, Lalsot (dausa), \\ Rajasthan 303511, India \\ *Corresponding author
}

A B S T R A C T

\section{Keywords}

Pre-breeding, Genetic Resources and Crop Improvement

Article Info

Accepted:

15 January 2019

Available Online:

10 February 2019
Pre breeding include all such activities related to the identification of desirable genes from the wild and weedy relatives and other unadapted materials and transfer these traits to an intermediate set of materials that breeders can use further in producing new varieties for farmers. It is the first step of crop improvement programs. It is essential for linking genetic diversity arising from wild relatives and other unimproved materials and it consists of identifying a useful character, capturing its genetic diversity and putting those genes into usable form. Pre-breeding activities designed to transferring resistance gene(s) to major diseases and insects, and tolerance to abiotic stresses, from wild relatives into cultivated through using introgression and incorporation techniques. Pre-breeding aims to provide breeders ready to use materials with specific traits of interest as well as a means to broaden the diversity of improved germplasm. It does not differ significantly from general framework of plant breeding and is considered as prior step of sustainable plant breeding. The present review focusing on all the aspects related to pre-breeding and will be use-full for student and scientific community.

\section{Introduction}

Plant breeding is an art and science of improving plants genetically for the benefit of humankind. Plant breeding is devoted to develop or improve crop cultivars with economic benefits for small-scale and commercial farmers. It is practiced worldwide by professional plant breeders. Plant breeders usually make crosses involving elite varieties/cultivars/lines. The modern cultivation practices of uniform high yielding varieties (HYVs) had reduced crop genetic diversity and led the exposure of crop plants to disease and insect pest epidemics. To counter these effects, plant breeder need to make deliberate efforts to diversify the gene pools of their crop to reduce genetic vulnerability. The genetic diversity of crop plants act as the foundation for the sustainable development of new varieties for present and future challenges. Genetic diversity provides an opportunity to develop improved crops/varieties through selection and hybridization, which are resistant to virulent pests and diseases and adapted to changing environmental conditions. Plant genetic resources for agriculture are the biological 
cornerstone of global food security. They comprises diversity of genetic material contained in traditional varieties, modern cultivars, crop wild relatives and other wild species (FAO, 2007).

Crop domestication and improvement can be described as a process of successive rounds of selection that ultimately results in the isolation of genetic diversity valuable to agriculture from ancestral wild species. Crop wild relatives (CWR) possess high level of genetic diversity that enabled them to survive in natural and adverse environments (Cooper et al., 2001).

The narrow genetic base of cultivars coupled with low utilization of genetic resources is the major factor limiting production and productivity globally. To exploit this genetic diversity pre-breeding offers a unique opportunity by introgression of desirable genes from wild germplasm into cultivated backgrounds readily used with minimum linkage drag. Pre-Breeding term was first coined by Rick in 1984.

It is an alternative term used for "genetic enhancement" and in recent times it has become an essential, planned part of all plant breeding activities. It refers to all activities designed to identify materials that cannot be used directly in breeding programmes, and further to transfer these traits to an intermediate set of materials that breeders can use further in producing new varieties for farmers.

Pre-Breeding is defined as transferring of useful genes from exotics or wild (unadapted sources) types into agronomical acceptable background / breeding material (FAO, 1996). Further, the Global Crop Diversity Trust defined pre-breeding as 'the art of identifying desired traits, and incorporation of these into modern breeding materials. In nut shell, prebreeding is the transfer or introgression of genes or gene combinations from unadapted sources into breeding materials including those that, although adapted have been subjected to any kind of selection for improvement.

Pre-breeding and its end product is expected to have merit to be included in ordinary breeding programs. Although there are some different concepts of exotics, Hallauer and Miranda (1981) consider that exotics for prebreeding purposes include any germplasm that does not have immediate usefulness without selection for adaptation for a given area. In this sense, exotic germplasms are represented by races, populations, inbred lines, etc.

Consequently, the results of crosses between adapted and exotic materials, where different proportions of introgression are obtained and evaluated, have been denominated as semiexotic materials. Pre-Breeding is focused to enhance genetic variability in the germplasm and the improved germplasm can be readily used in regular breeding programme for cultivar development (Lokanathan et al., 2003).

Pre-breeding aims to generate new base population for breeding programme through the use of a wider pool of genetic material (Haussmann et al., 2004). Pre-breeding has been used successfully in several crops (rice, tomato, soyabean, cotton, maize, wheat, barley, groundnut, chickpea, pigeon pea, sorghum, pearl millet) by transferring the genes from wild / exotic (unadapted) species into adapted material and improved many cultivated varieties for different qualitative and quantitative traits (Plunkett et al., 1987, Eshed and Zamir, 1996, Iqbal et al., 2001, Sebolt et al., 2000 and Seetharam, 2007). PreBreeding activities using promising landraces, wild relatives, and popular cultivars have been initiated in a diverse range of programs (Table 1). 
Table.1 Differences between pre breeding and traditional breeding

\begin{tabular}{|c|c|c|}
\hline Sr. No. & Pre breeding & Traditional Breeding \\
\hline 1 & $\begin{array}{l}\text { Pre-breeding is also known as genetic } \\
\text { enhancement. }\end{array}$ & $\begin{array}{l}\text { Traditional breeding is also known as sustainable } \\
\text { plant breeding. }\end{array}$ \\
\hline 2 & $\begin{array}{l}\text { It leads to genetic enhancement of } \\
\text { germplasm. }\end{array}$ & $\begin{array}{l}\text { It leads to development of productive } \\
\text { cultivars/hybrids. }\end{array}$ \\
\hline 3 & It leads to value addition. & It does not lead to value addition. \\
\hline 4 & $\begin{array}{l}\text { It leads to broadening the genetic } \\
\text { base of the population. }\end{array}$ & $\begin{array}{l}\text { It leads to development of improved cultivars } \\
\text { with narrow genetic base. }\end{array}$ \\
\hline 5 & $\begin{array}{l}\text { The chief breeding method is } \\
\text { backcross method. }\end{array}$ & $\begin{array}{l}\text { All breeding methods such as introduction, } \\
\text { selection, hybridization and mutation are used. }\end{array}$ \\
\hline 6 & $\begin{array}{l}\text { The end products are improved } \\
\text { germplasm line. }\end{array}$ & The end product is cultivar or hybrid. \\
\hline 7 & $\begin{array}{l}\text { The end product is used as parent for } \\
\text { developing improved cultivar, hybrid. }\end{array}$ & $\begin{array}{l}\text { The end product is used for commercial } \\
\text { cultivation. }\end{array}$ \\
\hline 8 & $\begin{array}{l}\text { It involves adapted and non-adapted } \\
\text { genotypes in crossing programme }\end{array}$ & It includes only adapted genotype \\
\hline 9 & It is a long term breeding programme. & $\begin{array}{l}\text { It is a short or medium term breeding } \\
\text { programme. }\end{array}$ \\
\hline 10 & $\begin{array}{l}\text { It is taken up by public sector plant } \\
\text { breeding organizations. }\end{array}$ & $\begin{array}{l}\text { It is taken up by both public and private sector } \\
\text { organizations. }\end{array}$ \\
\hline
\end{tabular}

\section{Objectives of pre-breeding}

It is generally taken up with the following breeding objectives.

Improved germplasm and associated genetic knowledge that enhance resistance expression and diversity.

Reduce genetic uniformity in crops through the use of a wider pool of genetic material to increase yield, resistance to pests and diseases, and other quality traits.

Identification of desirable traits/genes and their subsequent transfer into a suitable set of parents for further selection.

Improved parental stocks which can be readily utilized within breeding programs and improved selection methodologies.

Identify potentially useful genes in a wellorganized and documented gene bank

Designing strategies that lead to development of an improved germplasm that are ready to use in varietal development

\section{Why Pre-breeding is required}

The success of any crop improvement program depends on the availability of sufficient genetic variability, but this variability must be in conventionally usable form. Progress in breeding is limited due to lack of variability. Limited genetic base is apparent a threat to food security. Genetically uniform modern varieties are replacing the highly diverse local cultivars and landraces in agro-ecosystems. Genetic uniformity led to increased genetic vulnerability for pests and diseases. Search for new genes/traits for better adaptation due to change in climate. Evolving pest and pathogen populations: motivating plant breeders to look for new sources of resistance in gene banks. Pre-breeding is the most promising alternative to link genetic resources and breeding programmes. There are at least three distinct aspect of genetic enhancement. The first is to prevent genetic uniformity and consequent genetic 
vulnerability. Recently pre-breeding has become a necessary frequent and planned part of all plant breeding activities and germplasm diversification strategies. Genetic enhancement has a second important purpose that of raising yield levels to new heights. This goal is more often hoped for than achieved, but it is true that most breakthrough cultivars have highly diverse parentage. The semi-dwarf wheat, the high yield dwarf rice, the hybrid sorghums and even the maize cultivars are examples. In each case, extensive pre-breeding preceded development of the breakthrough, high-yield cultivars. The pre-breeding was used to adapt diverse kinds of germplasm to new genetic backgrounds and new geographic locals. Genetic enhancement is used to bring in new quality traits not found in local cultivars. New levels of protein percentage in wheat or unusual starch properties in maize are examples. It is first step in linking the genetic variability arising from wild relatives and other unimproved materials to utilize in crop improvement programme. It is collaborative approach between the germplasm curator and the plant breeder who need to work together to understand the scope and value of germplasm collections and how new traits from these collections can be bred into new varieties. The decision to use pre-breeding is based on the expected efficiency, outcome and efficacy of ultimately moving the target traits into cultivars for farmers and source of desired gene(s). It is necessary to go through Pre-breeding, if desired genes are available in gene bank accessions those are not welladapted to the target environment, closely related wild species that are easily crossed with the crop species and more distant wild species which are more difficult to cross.

\section{Significant outlook of pre breeding}

Classical approaches being used in crop improvement with the help of plant genetic resources (Cooper et al., 2001) are:

\section{Introgression}

Introgression, also known as introgressive hybridization, in genetics is the movement of a gene (gene flow) from one species into the gene pool of another by the repeated backcrossing of an interspecific hybrid with one of its parent species. Purposeful introgression is a long-term process; it may take many hybrid generations before the backcrossing occurs. It is transfer of one or more genes from exotic/un-adapted/wild stock to adapted breeding material. The concept of introgression through backcross was evolved by Dr. Edgar Anderson in cotton and was first visualized by Knight (1945).

\section{Incorporation}

Incorporation or broadening of genetic base refers to a large scale programme aiming to develop locally adapted population using exotic / un-adapted germplasm. The objective of incorporation is to produce new breeding populations that have very high proportions of unique, exotic-derived alleles in order to broaden substantially the crop's genetic base. Successful germplasm incorporation programs have been conducted in many crops.

\section{Wide crosses}

A cross of two individuals belonging to different species or different genera is known as wide cross. Such a cross can be (rarely) realized in nature - origin of new species and synthesis of new base populations But: it has to overcome barriers prohibiting such a cross by itself OR the development of fertile offspring. Wide crosses usually employed to widen the gene pool of a crop practically, most often used to transfer genes for resistance to biotic/abiotic stress. Wide crossing has been used with considerable success in some crops viz., blight resistance in potato, rust resistance in wheat and insect resistance in rice. 


\section{Decentralized participatory plant breeding}

Plant breeding programs differ from each other in different aspects (in the crop, in the facilities and in the breeder) but they all have in common some major stages such as creation of variability, selection and testing of experimental cultivars. A decentralizedparticipatory plant breeding program also function with the same line provided with some differences like most of the process takes place in farmers' fields, the decisions are taken jointly by the farmers and the breeder and the process can be implemented at a number of locations involving a large number of farmers evaluating different breeding materials.

\section{Marker assisted breeding}

Breeding methods based on DNA molecular marker patterns instead of, or in addition to, their trait values. It is a tool that can help plant breeders select more efficiently for desirable crop traits. When molecular markers are available, conveniently co-segregating with candidate genes, marker-assisted selection (MAS) or marker-aided selection may improve the efficiency of selections of simple traits in conventional plant breeding programs (Knapp, 1998; Podlich et al., 2004).

\section{Genetic transformation}

It is a process of horizontal gene transfer by which the genetic material carried by an individual cell is altered by the incorporation of foreign (exogenous) DNA into its genome.

\section{Significant applications of pre-breeding}

Pre-Breeding can be exploited to

Broaden the genetic base, to reduce vulnerability

Identify traits in exotic materials and moving those genes into material more readily accessed by breeders.

Move genes from wild species into breeding populations when this appears to be the most effective strategy.

Identify and transfer of novel genes/traits from unrelated species using genetic transformation techniques.

\section{Pre-breeding: bridge between Gene pool and crop improvement}

There is currently a major gulf between the operations of plant genetic resource collections and modern plant breeding that is potentially a major restriction in the development of improved varieties which needs to meet new agronomic as well as environmental challenges. This disconnect can be bridged through pre-breeding that is based on the characterization of genetic resources and then transferring the traits of interest into suitable and agronomical adapted genetic backgrounds (Tanksley and McCouch, 1997).

The gene pool is the total genetic variation in the breeding population of a species and closely related species capable of crossing with it. The gene pool of a crop is composed of botanical varieties, landraces, inbred lines, ancient landraces, obsolete and modern cultivars, related wild species, subspecies, and weedy companion species (Haussmann et al., 2004). Linkage drag is the most important factor responsible for low use of germplasm in crop improvement and is the major reason for the need for pre-breeding (Ortiz, 1999). While using unknown and wild germplasm, comparatively more efforts, time and resources are required to break undesirable linkage drag during the development process, particularly for regional adaptability to climates, crop management, biotic and abiotic stresses, and overall agronomic performance. This makes the breeding program comparatively more lengthy and cumbersome 
(Fig. 1). Pre breeding offers the solution to overcome the problem of linkage drag and others arising normal breeding programme. So, we can consider the Pre-breeding as a link between plant genetic resources and plant breeding.

\section{Requirement for pre-breeding}

Pre- Breeding act as an interface of conservation of PGR and breeding. Therefore it is a multidisciplinary approach and required the followings.

Collection of underrepresented diversity, informed by gap analyses based on taxonomic designations and eco-geographic information along with detailed passport data to both conserve the breadth of diversity available in the wild and facilitate predictive trait mining based on eco-geographic data.

Coordinated evaluation and sharing of prebreeding products across environmental conditions to better understand genotypeenvironment interactions;

Improved information, sharing of that information and feedback, especially with regards to genotypic and phenotypic data and the way they are linked between genetic resource conservationists, pre-breeders, breeders, and end users.

Enhanced coordination between basic and applied research communities.

\section{Problems associated with Genetic Enhancement through pre-breeding}

Though pre-breeding avoid the many problems of normal breeding programme, but on the other hand, pre-breeding also comes up with some problems particularly when genes are need to be introgressed from wild species. Some problems are listed below:

Cross incompatibility in inter-specific crosses.
Stability barriers and chromosome pairing in hybrids which restricts the access to genes from wild species into cultivated ones.

Linkage drag.

Hybrid inviability and sterility.

Small sample size of inter-specific hybrid population.

Restricted genetic recombination in the hybrid population.

Lack of availability of donors for specific traits viz. resistance to diseases and pests.

Difficulties in exchange and accessibility of cultivated germplasm material due to legal restrictions like IPR. (Loknathan et al., 2003).

\section{Challenges and future prospects of pre- breeding}

The major challenges of pre-breeding are lack of characterization, evaluation of genetic diversity, documentation of data; inter species relationship and strong breeding program and funding sources. The above mentioned problems draw the attention towards urgent need for collection, characterization and documentation of wild species, including crop wild relatives, due to increased likelihood of extinction for narrowly adapted and endemic species. There is a rise in demand of novel genes in germplasm/ gene banks collections to make the agriculture tolerant/resistant against biotic and abiotic odds. Genome mapping, decoding of genes and synteny among the genes could be assigned to conceal the stress tolerance and can be utilized for crop improvement.

The potential of genetic transformation technique could be exploited to transfer the desired gene(s) form the tertiary gene pool and/or beyond. New breeding strategies and bioinformatics tools are required to use the information gathered from genetic and genome analysis programs for dealing with complex traits more effectively. 
Pre-Breeding work attempted in different crops

Wild Species possesses the greater amount of genetic variation which can be exploited to improve the crops (Basey, 1906). LAMP is a real example of pre-breeding program, which includes 12 countries (Argentina, Bolivia,
Brazil, Colombia, Chile, U.S., Guatemala, Mexico, Paraguay, Peru, Uruguay and Venezuela). LAMP evaluated 15,000 accessions in the first stage, with close cooperation of the public and private sectors. Pre- Breeding work has been attempted in different crops which are listed below (Table 2).

Table.2

\begin{tabular}{|c|c|c|c|}
\hline S. N. & Crop & Remark & Reference \\
\hline 1. & $\begin{array}{l}\text { Domestic } \\
\text { Bean }\end{array}$ & $\begin{array}{l}\text { Wild relatives are a potential source of novel } \\
\text { alleles that can be exploited for the } \\
\text { improvement of yield and other quantitative } \\
\text { traits. }\end{array}$ & Acosta-gallegos et al., 2007 \\
\hline 2. & Soybean & $\begin{array}{l}\text { Useful traits have been identified and } \\
\text { introgressed in cultivated species from wild } \\
\text { species through inter-specific hybridisation }\end{array}$ & Sebolt et al., 2000) \\
\hline 3. & Rice & $\begin{array}{l}\text { Continuous efforts are being made to transfer } \\
\text { the desired traits into the cultivated varieties } \\
\text { from the rice accessions which are stored in } \\
\text { gene banks due to narrow genetic base. }\end{array}$ & Plunkett et al., 1987 \\
\hline 4. & Maize, & $\begin{array}{l}\text { Value of exotic resource has yet to be explored } \\
\text { in polymorphic genome which is resulted due } \\
\text { to gene flow between cultivated and wild } \\
\text { species. }\end{array}$ & $\begin{array}{l}\text { Cantrell et al.,1996 and Wang et } \\
\text { al 1999, Luciano and Peterinain } \\
\text { 2000, Nass and Paterniani, } 2000\end{array}$ \\
\hline 5. & Tomato & $\begin{array}{l}\text { Different genes for disease resistance have } \\
\text { been incorporated from various wild resources } \\
\text { in commercial hybrids through recurrent back } \\
\text { cross and each resides on a small independent } \\
\text { chromosome segment from one of the diverse } \\
\text { donor species. An important gene was } \\
\text { introduced from the wild tomato species } \\
\text { (Lycopersicom pennellii B.), which resulted } \\
\text { into raised level of Pro-vitamin A in the fruit } \\
\text { by more than } 15 \text { fold. }\end{array}$ & Ronen et al., 2000 \\
\hline 6. & Cotton & $\begin{array}{l}\text { Pre-breeding has been attempted in cotton } \\
\text { (since1970) in different countries and several } \\
\text { varieties were developed using wild species for } \\
\text { resistance to biotic stress (sucking pest), } \\
\text { Abiotic Stress (drought tolerance) and Quality } \\
\text { improvement (fibre quality)Texas, USA. }\end{array}$ & Lokanathan et al., 2003 \\
\hline 7. & $\begin{array}{l}\text { Groundnut, } \\
\text { Pigeon pea, } \\
\text { chickpea, }\end{array}$ & $\begin{array}{l}\text { Improved the existing cultivars using wild } \\
\text { species for resistance to biotic stress and } \\
\text { abiotic Stress and quality improvement }\end{array}$ & ICRISAT, 2004 \\
\hline
\end{tabular}




\begin{tabular}{|c|c|c|c|}
\hline & $\begin{array}{l}\text { sorghum and } \\
\text { pearl millet }\end{array}$ & & \\
\hline 8 & spring barley & $\begin{array}{l}\text { Pre breeding has been attempted for } \\
\text { improvement of biotic/abiotic stresses and } \\
\text { agronomic and nutrition-related traits }\end{array}$ & Vellve, 1992, D.E. Falk, 1990 \\
\hline 9 & Wheat & $\begin{array}{l}\text { successful introduction of useful genes from } \\
\text { wild species into cultivated species for specific } \\
\text { traits }\end{array}$ & $\begin{array}{l}\text { Seetharam, 2007, Dalrymple, } \\
\text { 1986, Valkoun, 2001 }\end{array}$ \\
\hline 10 & $\begin{array}{l}\text { Sugarcane, } \\
\text { sunflower, } \\
\text { cotton }\end{array}$ & $\begin{array}{l}\text { successful introduction of useful genes from } \\
\text { wild species into cultivated species for specific } \\
\text { traits }\end{array}$ & Seetharam, 2007 \\
\hline 11 & mulberry & $\begin{array}{l}\text { Crosses between cultivated (M. indica) and } \\
\text { different wild species (M. cathayana, M. } \\
\text { pendulata and M. serrata) for improve the } \\
\text { quality }\end{array}$ & $\begin{array}{l}\text { Takader and Rao, 2002, Tikader } \\
\text { and Thangavelu, 2002, Tikader } \\
\text { and Dandin 2001, Tikader and } \\
\text { Ananda 2003, Tikader and } \\
\text { Dandin, } 2007\end{array}$ \\
\hline
\end{tabular}

Fig.1 Pre-breeding as a bridge between genetic resources and crop improvement

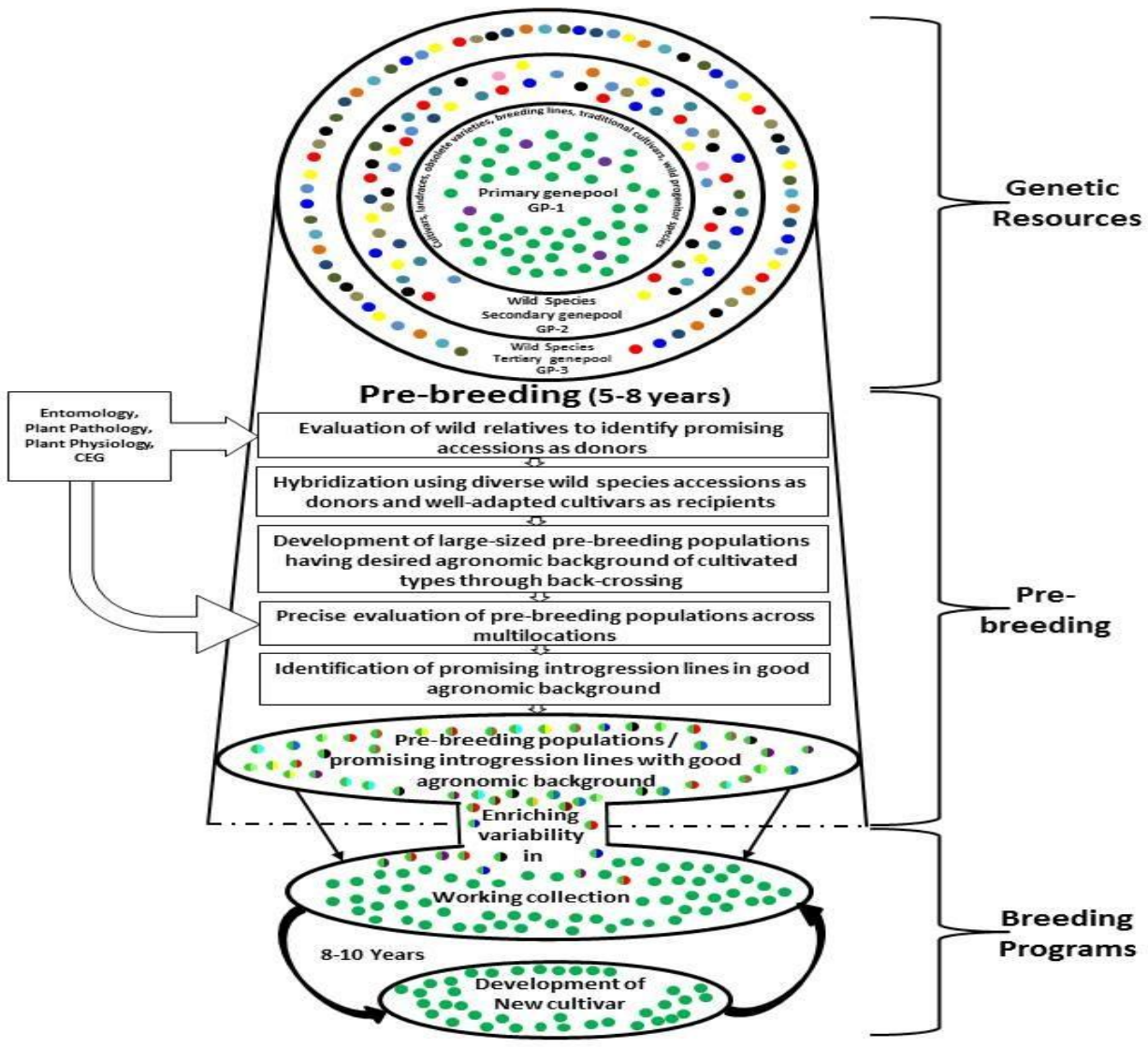

(Figure adopted from: https://www.biotecharticles.com/Agriculture-Article/Role-of-Pre-breeding-in-Crop-Improvement-3763.html)

In conclusion, for field crops improvement, sufficient genetic diversity exists in the form of landraces and wild relatives, which carry several useful genes for cultivar 
improvement. However, utilization of these resources in breeding programs is timeconsuming and resource demanding. To overcome this, pre-breeding activities should be initiated to generate new genetic variability using promising landraces and wild relatives for use by the breeders in crop improvement programs. Pre-breeding should focus on the continuous supply of useful variability into the breeding pipeline to develop new highyielding cultivars with a broad genetic base, pre-breeding should not focus on increasing yield. Though pre breeding is useful to enrich the primary gene pool for cultivar improvement, it is a time-consuming and difficult affair as well. Further, linkage drag associated with utilizing wild relatives makes the pre-breeding activities much more cumbersome. Genomic-assisted pre-breeding will help to overcome the linkage drag and will facilitate focused transfer of useful genes/segments from wild relatives for genetic enhancement.

\section{References}

Acosta-Gallegos J., Kelly J. D., Gepts P. 2007. Prebreeding in common bean and use of genetic diversity from wild germplasm. Crop Sci. 47: 44-59

Bessey C.E. 1906. Crop improvement by utilizing wild species.Am. Breed.Assoc.11, 112-118.

Cantrell R. P., Christopher R., Dowswell C. R., Paliwal R. L. (1996). Maize in the Third World. Boulder, CO: Westview Press

Cooper, H.D., Spillane, C. and Hodgkin, T. 2001. Broadening the genetic base of crops: an overview. In: Cooper HD, Spillane $\mathrm{C}$ and Hodgkin $\mathrm{T}$ (eds.) Broadening the Genetic Base of Crop Production. Wallingford: CABI Publishing in cooperation with FAO and IPGRI, CAB International, pp.1-23.

Dalrymple D. G. 1986. Development and
Spread of High-Yielding Wheat Varieties in Developing Countries. 7th Edn Washington, DC: US Agency for International Development.

Eshed Y, Gera, G. and Zamir, D. 1996. A genome-wide search for wild-species alleles that increase horticultural yield of processing tomatoes Theor Appl Genet 93: 877-886.

Eshed, Y. and Zamir, D. 1996. Less than additive epistatic interaction of QTL. In tomato, Genetics 143. 1807-1817.

FAO, 1996. Global action plan for the conservation and sustainable utilization of plant genetic resourcesfor food and agriculture:Leipzig declaration International Technical Conference on plant genetic resources Jure Leipzig, Germany.

FAO. 2007. Adaptation to Climate Change in Agriculture, Forestry and Fisheries: Perspective, framework and priorities. Rome, Italy, Interdepartmental Working Group on Climate Change, FAO. pp.32.

Hallauer, A.R. and Miranda, J. B. 1981. Quantitative genetics in maize breeding Lowa State Univ. Press. Ames Lowa.

Haussman, BIG. Parzies, H.K. Presterl, T. Susic, Z. and Miedaner, T. 2004. Plant genetic resources in crop improvement. Plant Genetic Resources, 2 (1): 3-21.

ICRISAT, International Crop Research Institute for semi-arid tropics 2004. Success story 22 Jan 2004. Patancheru, Hyderabad, India. online website. www. Icrisat.org

Iqbal, M.J. Reddy, O.U.K. EI-Zik, K.M. and Peppes, A.E. 2001. A genetic bottle neck in the evolution under domestication of upland cotton Gossypium hirusutum L. examined using DNA finger printing. Theor. Appl. Genet. 103, 547 - 554.

Knapp S. J. 1998. Marker-assisted selection as a strategy for increasing the probability of selecting superior genotypes. Crop Sci. 38:1164-1174. 
Lokanathan, T.R.,; Phundan singh,: Agarwal, D.K.; Punit Mohan; Suman Bala Singh, Vinita Gotmare and Singh, V.V. 2003. Genetic enhancement in cotton Technical Bulletin from CICR Report No. 26.

Luciano, L.N. and Peterinain. E. (2000). Prebreeding: A link between genetic resources and maize breeding. Sci. Agric. 57, (3) 1-10

Nass L. L., Paterniani E. 2000. Pre-breeding: a link between genetic resources and maize breeding. Sci. Agric. 57: 581-587.

Ortiz, R. (1999) Genetic Diversity of cultivated crops and in situ conservation of genetic resources. Botanica Lithuanica suppl. 2:15-30.

Peloquin, S.J., Yerk, G.L. Werner, J.E. and Darma E. (1999). Potato breeding with haploids and 2n gametes. Genomes. 31: 1000-1004.

Plunkett, D.L. Smith, N.J.H.; Williams, J.T. and Anishetty, N.M. 1987. Gene banks and the worlds food. Princton, Univ. Press. Princeton New Jersey.

Podlich D.W., Winkler C.R., Cooper M. 2004. Mapping as you go: an effective approach for marker-assisted selection of complex traits. Crop Sci. 44:1560-1571.

Rick, C.W. 1984. Plant germplasm resources. In: D.A. Evans, W.R. Sharp, P.V. Ammirato and Y. Yamada (eds). Hand book of cell culture. Mac Milan. New York p. 9 -37.

Ronen, G. Carmel, G.L. Zamir, D. and Hirchberg, J. 2000. An alternative pathway to carotene formation in plant chromoplasts discovered by map-based cloning and old gold color mutation in tomato. Proc. Natl. Acad. Sci. USA, 97:11102- 11107

Sebolt, A.M. Shoemaker, R.C. and Diers, B.W. 2000. Analysis of a quantitative trait locus allele from wild soya bean that increases seed protein concentration in soy bean. Crop Science. 40:1438-1444.

Seetharam, A. 2007. Pre-breeding: An important step in the effective utilization of conserved germplasm. National workshop on utilization of wild mulberry genetic resources 2nd \& 3rd Nov. 2007. 9-16.

Tanksley, S.D. and Mc Couch, S. 1997. Seed banks and molecular maps: unlocking genetic potential from the wild. Science 277: 1063-1066.

Tikader, A. and Ananda Rao.A. 2003. Inter and Intra-specific hybridization studies in mulberry (Morus spp.) germplasm. Bull. Indian. Acad. of Seric. (6): 17-22

Tikader, A and Dandin, S.B. 2001. Breeding behaviour of some wild mulberry. Indian Silk 40 (1):9-10.

Tikader, A. and Kamble C.K. 2007. Survival potential of different mulberry (Morus Spp.) accessions. Geobios. 34: 282-286.

Tikader, A. and Thangavelu, K. 2002. Breeding performance of some wild mulberry (Morus Spp.). In: Proc. Nat. Conf. Rec. Trends in Plant Sci. Res. 14 15. Nov. 106-111.

Valkoun J. J. (2001). Wheat pre-breeding using wild progenitors. Euphytica 119, $17-23$.

Vellve R. 1992. Saving the Seeds: Genetic Diversity and European Agriculture. London: Earthscan Publication.

\section{How to cite this article:}

Jain, S.K. and Omprakash. 2019. Pre-breeding: A Bridge between Genetic Resources and Crop Improvement. Int.J.Curr.Microbiol.App.Sci. 8(02): 1998-2007. doi: https://doi.org/10.20546/ijcmas.2019.802.234 